DOI: $10.19195 / 2084-5065.48 .4$

\title{
Z problematyki kary ograniczenia wolności w świetle nowelizacji kodeksu karnego
}

\author{
ZOFIA SIENKIEWICZ
}

Rozważania o nowym ujęciu kary ograniczenia wolności oraz jej roli jako środka polityki karnej skłaniają do sformułowania wstępnych uwag o regulacji tej kary oraz o zakresie jej stosowania przed nowelizacją kodeksu karnego z 2015 roku ${ }^{1}$. Nie ulega wątpliwości, że kara ograniczenia wolności w jej poprzedniej regulacji w pełni odpowiadała ówczesnym założeniom kodeksu karnego z 1997 roku. Jej znaczącą rolę wyraźnie podkreślało wówczas uzasadnienie kodeksu karnego, w którym akcentowano rezygnację ze zbędnej represyjności i dominacji kary pozbawienia wolności na rzecz innych kar wolnościowych oraz środków karnych $^{2}$. Wprowadzenie między innymi szerszego zakresu sankcji alternatywnie określonych, nowego ujęcia kary grzywny oraz kary ograniczenia wolności pozwalało, zgodnie z założeniami kodeksu karnego, na prowadzenie racjonalnej, wyrażającej współczesne tendencje, polityki karnej. Niejednokrotnie zarzucano jednak kodeksowi karnemu z 1997 roku, że jego założenia polityczno-kryminalne są w istocie oparte na liberalizacji odpowiedzialności karnej ${ }^{3}$. Naturalną konsekwencją takich

1 Ustawa z 20 lutego 2015 r. o zmianie ustawy — Kodeks karny oraz niektórych innych ustaw, Dz.U. z 2015 r., poz. 396.

2 Nowe kodeksy karne - z 1997 roku z uzasadnieniami, Warszawa 1997, s. 150.

3 O założeniach polityczno-kryminalnych kodeksu karnego z 1997 r. por. między innymi K. Buchała, System kar, środków karnych i zabezpieczajacych w projekcie kodek- 
polityczno-kryminalnych założeń kodeksu karnego z 1997 roku było wzmocnienie roli i zakresu stosowania kar wolnościowych: grzywny i kary ograniczenia wolności. Zmieniono zatem tradycyjny układ w katalogu kar, rozpoczynając od kar łagodniejszych, a nie - jak poprzednio — od kar najsurowszych ${ }^{4}$. Takie uplasowanie kar bez pozbawienia wolności było nie tylko zabiegiem techniczno-legislacyjnym, lecz miało wyraźny walor polityczno-kryminalny, zmierzający do odmiennego określenia miejsca tych kar, a zatem również kary ograniczenia wolności, w systemie kar kodeksu karnego ${ }^{5}$. Nie ulega wątpliwości, że taka regulacja miała wskazywać sędziom ustawowe priorytety w wyborze kar. Najistotniejszym jednak w tym względzie przepisem realizującym założenia polityczno-kryminalne kodeksu karnego była dyrektywa z art. 58 $\S 1$ k.k. ${ }^{6}$, nakazująca traktowanie bezwzględnej kary pozbawienia wolności jako ultima ratio, ustanawiająca równocześnie prymat kar wolnościowych we wszystkich tych wypadkach, w których sąd ma możliwość wyboru rodzaju kary. Wskazana przez ustawodawcę w art. $58 \S 1$ k.k. preferencja kar wolnościowych rozciągała się, jak podkreślano niekiedy w doktrynie ${ }^{7}$, także na występki zagrożone wyłącznie karą pozbawienia wolności, nieprzekraczającą 5 lat (art. $58 \S 3$ k.k.) ${ }^{8}$. Wspomniany przepis dawał bowiem sądowi możliwość orzeczenia grzywny lub kary ograni-

su karnego z 1990 r., PiP 1991, nr 6, s. 20-30; A. Zoll, Założenia polityki kryminalnej w projekcie kodeksu karnego, PiP 1994, nr 5, s. 5-11; T. Kaczmarek, Kryminalno-polityczne założenia nowego kodeksu karnego, „Nowa Kodyfikacja Prawa Karnego” 3, 1988, s. $11 \mathrm{n}$.

4 Podobny układ dotyczył również sankcji karnych w części szczególnej kodeksu karnego.

5 S. Pawela, Kara grzywny w projekcie kodeksu karnego i wykonawczego z 1990 r., PiP 1999, nr 3, s. 77.

6 Art. 58 § 1 stanowił: „Jeżeli ustawa przewiduje możliwość wyboru rodzaju kary, sąd orzeka karę pozbawienia wolności bez warunkowego zawieszenia jej wykonania tylko wtedy, gdy inna kara lub środek karny nie może spełnić celów kary".

7 Takie stanowisko por. K. Buchała, [w:] K. Buchała, A. Zoll, Kodeks karny. Czesść ogólna. Komentarz do k.k., Zakamycze 1998, s. 430; A. Marek, Kodeks karny. Komentarz, Warszawa 2010, s. 193.

8 Art. 58 § 3 k.k. stanowił: ,Jeżeli przestępstwo zagrożone jest karą pozbawienia wolności nieprzekraczającą 5 lat, sąd może orzec zamiast kary pozbawienia wolności grzywnę albo karę ograniczenia wolności do lat 2, w szczególności jeżeli orzeka równocześnie środek karny; karę ograniczenia wolności wymierza się w miesiącach i latach”. 
czenia wolności nawet wówczas, gdy nie była ona przewidziana w ustawowym zagrożeniu za dany typ przestępstwa. W doktrynie brakowało zgodności, czy przepis art. $58 \S 3$ k.k. ustanawia dyrektywę, czy zasadę wymiaru kary i czy ustanawia prymat kar wolnościowych przed karą pozbawienia wolności. Brakowało bowiem w tym przepisie wyraźnych sugestii w kwestii przysługującego wyboru rodzaju kary ${ }^{9}$. Pozostawiając na uboczu szczegółowe w tym względzie doktrynalne rozważania, należy podkreślić, że ówczesne przepisy kodeksu karnego stwarzały szerokie możliwości stosowania kary ograniczenia wolności - nie tylko przewidując ją w wielu sankcjach alternatywnych ${ }^{10}$, lecz umożliwiając jej stosowanie na podstawie art. $58 \S 3 \mathrm{k} . \mathrm{k}$. oraz w razie nadzwyczajnego złagodzenia kary (art. $60 \S 6$ pkt 3 i 4). Jest zatem w pełni uzasadnione, że tworząc szeroki zakres stosowania kary ograniczenia wolności, ustawodawca starał się tak uregulować treść tej kary, aby mogła realizować wyznaczone cele penalne. Dyskusyjne jest natomiast, w jakim stopniu i w jaki sposób kara ograniczenia wolności mogłaby te cele in concreto realizować.

Nie przytaczając szczegółowo nieobowiązujących już przepisów regulujących karę ograniczenia wolności, należy wspomnieć, że jej treścią było znaczne ograniczenie wolności skazanego w zakresie między innymi wyboru miejsca pracy, wyboru pracy, dysponowania wynagrodzeniem za pracę czy dysponowania wolnym czasem. Przepis art. 34 § 2 k.k. był jasny i stanowił, że w czasie odbywania kary pozbawienia wolności skazany: 1. nie może bez zgody sądu zmienia miejsca stałego pobytu; 2. jest obowiązany do wykonywania nieodpłatnej niekontrolowanej pracy cele społeczne ${ }^{11} ; 3$. ma obowiązek udzielania wyjaśnień dotyczących przebiegu odbywania kary. Jeżeli sprawca zatrudniony był w uspołecznionym zakładzie pracy, sąd mógł, zamiast obowiązku pracy, orzec po-

9 V. Konarska-Wrzosek, Dyrektywy wyboru kary w polskim ustawodawstwie karnym, Toruń 2008, s. 125-128; W. Wróbel, [w:] Kodeks karny. Część ogólna. Komentarz, t. 1, red. A. Zoll, Warszawa 2012, s. 808-810.

10 Wedle obliczeń R. Giętkowskiego kara ograniczenia wolności przewidziana była sankcjach części szczególnej aż w 98 przepisach — R. Giętkowski, Kara ograniczenia wolności w polskim prawie karnym, Warszawa 2007, s. 59.

11 Art. 35 § 1 k.k. stanowił: „Nieodpłatna kontrolowana praca na cele społeczne jest wykonywana w wymiarze od 20 do 40 godzin w stosunku miesięcznym”. 
trącenia od 10 do $25 \%$ wynagrodzenia za pracę w stosunku miesięcznym (art. 35 § 2 k.k.). Ogólnie można powiedzieć, że karę ograniczenia wolności charakteryzowały dolegliwości o charakterze wolnościowym, osobistym oraz ekonomicznym ${ }^{12}$. Z orzeczeniem kary ograniczenia wolności wiązała się też możliwość nałożenia, jak stanowił art. 36 § k.k., wielu obowiązków o charakterze fakultatywnym, probacyjnym, które były przewidziane w art. $72 \mathrm{k} . \mathrm{k}$. w przepisach o warunkowym zawieszeniu wykonania kary ${ }^{13}$. Tak ujęta kara ograniczenia wolności zbliżała się w swej istocie do instytucji probacyjnych, przy czym taką ocenę uzasadniał w pewnym stopniu przepis (art. $36 \S 1$ k.k.) o możliwości zastosowania, przy orzeczeniu tej kary, dozoru ${ }^{14}$. W doktrynie prawa karnego wyraźnie jednak podkreślano, że różnice pomiędzy instytucjami probacyjnymi a karą ograniczenia wolności są tak znaczące, że nie pozwalają uznać kary ograniczenia wolności za środek probacyjny. O powiązaniu z probacją mogła jednak świadczyć przewidziana przed nowelizacją z 2015 roku możliwość warunkowego zawieszenia wykonania kary ograniczenia wolności (art. $69 \S 1$ k.k.) ${ }^{15}$. Rozszerzenie możliwości stosowania instytucji warunkowego zawieszenia wykonania kary również na karę ograniczenia wolności było w doktrynie prawa karnego przedmiotem licznych uwag ${ }^{16}$. Najogólniej doktryna prawa karnego wyrażała wobec tej instytucji wyraźny sceptycyzm, podkreślając, że wprowadzenie do kodeksu karnego możliwości warunkowego zawieszenia wykonania kary ograniczenia wolności było nieuzasadnione ${ }^{17}$. Również

12 K. Buchała, A. Zoll, Polskie prawo karne, Warszawa 1995, s. 367.

$13 \mathrm{~W}$ pierwotnym ujęciu k.k. były to obowiązki wymienione w art. 72 pkt 2,3 lub 5 oraz $\S 2$ k.k., a następnie po zmianach ustawą z 5 listopada 2009 r. (Dz.U. Nr 206, poz. 1589) obowiązki wymienione w art. 72 k.k.

14 Por. A. Marek, Prawo karne, Warszawa 2004, s. 261; M. Szewczyk, [w:] Kodeks karny. Część ogólna. Komentarz, t. 1, red. A. Zoll, s. 601-602.

15 Przepisy kodeksu karnego regulowały pozytywne przesłanki warunkowego zawieszenia kary ograniczenia wolności (art. $69 \S 1$ i $\S 2$ ) oraz negatywne przesłanki (art. $69 \S 3$ i $\S 4$ k.k.), a także określały krótszy (od 1 roku do 3 lat) okres próby (art. 70 $\S 1$ pkt 2 k.k.).

16 Obszernie na temat warunkowego zawieszenia wykonania kary ograniczenia wolności pisze R. Giętkowski, op. cit., s. 139-148.

17 A. Zoll, [w;] Kodeks karny. Czesść ogólna. Komentarz, t. 1, red. A. Zoll, s. 947. Odmienne zdanie por. A. Marek, Prawo karne, s. 300. 
praktyka nie dostrzegała możliwości ani zalet warunkowego zawieszenia wykonania kary ograniczenia wolności i orzekała karę ograniczenia wolności w tej postaci w ilościach ,śladowych”. Trudno się zatem dziwić, że przepisami nowelizacyjnymi z 2015 roku instytucja warunkowego zawieszenia wykonania kary ograniczenia wolności została usunięta. W motywach ustawodawczych decyzję o rezygnacji z takiej postaci kary ograniczenia wolności uzasadniano przede wszystkim tym, że kara ograniczenia wolności jest już nasycona elementami probacyjnymi, a po zmianie z 2015 roku treść tej kary będzie w jeszcze większym stopniu wzmocniona tymi elementami. Orzekanie kary ograniczenia wolności $\mathrm{z}$ warunkowym zawieszeniem wykonania nie znajduje więc uzasadnienia $^{18}$. Znaczące zmiany dotyczące kary ograniczenia wolności wprowadziła ustawa nowelizacyjna z 5 listopada 2009 roku $^{19}$, między innymi zakaz orzekania kary ograniczenia wolności związanej z obowiązkiem nieodpłatnej kontrolowanej pracy na cele społeczne, jeżeli stan zdrowia oskarżonego lub jego właściwości i warunki osobiste uzasadniają przekonanie, że oskarżony nie wykona tego obowiązku (art. 58 §a k.k.). Inną zmianą było ustalenie jednego celu społecznego, na który mają być dokonywane potrącenia $\mathrm{z}$ wynagrodzenia oraz nieodpłatna, kontrolowana praca; kolejną zmianą było uchylenie przepisu o dozorze (art. $36 \S 1$ k.k. $)^{20}$. Wymiar kary ograniczenia wolności był daleki od represyjności i wynosił nadal od miesiąca do 12 miesięcy, chyba że ustawa stanowiła inaczej (art. $34 \S 1$ k.k.) ${ }^{21}$. Po nowelizacji z 5 listopada 2009 roku podstawowa górna granica kary ograniczenia wolności nie uległa zmianie (wynosiła nadal 12 miesięcy), lecz mogła być podwyższona i wynosić w niektórych przypadkach 2 lata (art. $38 \S 2$ k.k., art. $58 \S 3$ k.k., art. $86 \S 1$ k.k.).

18 Uzasadnienie rządowego projektu ustawy o zmianie ustawy — Kodeks karny $\mathrm{i}$ innych ustaw z projektami aktów wykonawczych z 15 maja 2014 r., http://www.sejm. gov.pl/sejm7.nsf/druk.xsp nr2393, s. 15-16; por. też J. Majewski, Kodeks karny. Komentarz do zmian 2015, Warszawa 2015, s. 224-225.

19 Ustawa z 5 listopada 2009 r. o zmianie ustawy - Kodeks karny, ustawy — Kodeks postępowania karnego, ustawy - Kodeks karny wykonawczy, ustawy — Kodeks karny skarbowy i innych ustaw, Dz.U. Nr 206, poz. 1589.

20 O tych zmianach por. M. Szewczyk, [w:] Kodeks karny. Część ogólna. Komentarz, t. 1, red. A. Zoll, s. 597.

21 R. Giętkowski, op. cit., s. 69-70. 
Omawiając poprzednią regulację kary ograniczenia wolności (do nowelizacji z 2015 roku), należy podkreślić, że szeroko ustanowiony zakres jej stosowania teoretycznie umożliwiał odegranie przez tę karę znaczącej roli w zwalczaniu drobnej i średniej przestępczości. Tymczasem kara ograniczenia wolności w praktyce nie zdała egzaminu z powodu błędów w ustawowym ujęciu, a przede wszystkim znacznych trudności wykonawczych, dlatego sądy orzekały ją stosunkowo rzadko ${ }^{22}$. Kara ograniczenia wolności w pierwszych latach po wejściu w życie kodeksu karnego z 1997 roku stanowiła niewielki odsetek orzekanych kar (zaledwie 7-10\%). Kolejne lata - 2000-2014 — nie przyniosły zasadniczej zmiany, istotniejszą rolę odgrywała tu kara grzywny (20-22\%). Politykę karną zdominowała natomiast kara pozbawienia wolności z warunkowym zawieszeniem wykonania (około 55-60\% orzeczonych kar) ${ }^{23}$. Reasumując, należy zaznaczyć, że praktyka orzekania kar po wejściu w życie kodeksu karnego z 1997 roku nie odpowiadała polityczno-kryminalnym założeniom tego kodeksu, który odchodząc od zbędnej represyjności, ustanawiał prymat kar wolnościowych jako głównego instrumentu polityki karnej do zwalczania drobnej i średniej przestępczości. Dotychczasowa polityka karna wymagała zatem poważnej zmiany, która byłaby oparta na odmiennej ustawowej regulacji kar i środków karnych oraz zasad ich wymiaru. Taką rolę wyznaczono nowelizacji z 20 lutego 2015 roku. W uzasadnieniu projektu ustawy nowelizacyjnej znajdujemy ostrą krytykę praktyki zbyt częstego stosowania kary pozbawienia wolności z warunkowym zawieszeniem jej wykonania, co w odbiorze społecznym postrzegane jest jako fikcyjna dolegliwość, dlatego cel probacyjny nie jest przez nią realizowany. Tymczasem, jak dalej czytamy w uzasadnieniu, ,konieczne jest szybkie orzekanie kar realnie dotkliwych, co skłania do tego, by karę pozbawienia wolności z warunkowym zawieszeniem jej wykonania zamienić niemal w całości na orzekanie grzywny i szerzej ujętej kary ograniczenia wolności" ${ }^{24}$. Propozycja nowej strategii polityczno-kryminalnej wymagała zatem przede wszystkim poważnej zmiany w przepisach regulujących

22 Podkreślał to między innymi A. Marek, Prawo karne, s. 260.

23 Statystyka sądowa, cz. 3. Prawomocne skazania osób dorosłych. Dane oraz obliczenia procentowe podane za: A. Marek, V. Konarska-Wrzosek, Prawo karne, Warszawa 2016, s. 381; por. też dane statystyczne, jakie podaje R. Giętkowski, op. cit., s. 25-32.

24 Uzasadnienie rządowego projektu..., s. 5. 
karę grzywny, karę ograniczenia wolności oraz innych przepisach, które mogłyby mieć wpływ na zakres stosowania kar wolnościowych.

Wstępnie można zaryzykować twierdzenie, że najpoważniejsze zmiany w systemie kar objęły właśnie karę ograniczenia wolności. Jak podkreślano w uzasadnieniu nowelizacji z 2015 roku, zasadniczej przebudowie podlega treść kary ograniczenia wolności, która „staje się najbardziej elastyczną i możliwą do konkretyzowania a causu ad casum" ${ }^{25}$. Mając na uwadze tak wyraźną deklarację zawartą w motywach ustawodawczych, można postawić pytanie, w jaki sposób ustawodawca uatrakcyjnia tę karę i czyni ją bardziej plastyczną. Jarosław Majewski, oceniając wstępnie nową regulację kary ograniczenia wolności, podkreśla, że umożliwia ona sądowi — w o wiele szerszym zakresie — kształtowanie jej dolegliwości w sposób dostosowany do konkretnego sprawcy i konkretnej sprawy ${ }^{26}$. Istotną zmianą, ważną dla prawidłowego kształtowania dolegliwości kary ograniczenia wolności, jest wydłużenie czasu trwania tej kary, ustalające obecnie jej wymiar w granicach od miesiąca do 2 lat, a nie - jak poprzednio - do 12 miesięcy. Nie ulega wątpliwości, że umożliwia to, niezbędne w konkretnych wypadkach, dłuższe oddziaływanie dolegliwości tej kary na skazanego. Wydłużenie granic wymiaru kary ograniczenia wolności ułatwia też rozłożenie w czasie poszczególnych obowiązków składających się na jego treść, a po zwiększeniu ich intensywności kara ograniczenia wolności staje się bardziej efektywnym środkiem polityki karnej. Górna granica kary ograniczenia wolności, określona na 2 lata, nie zmienia się obecnie i pozostaje identyczna przy karze ograniczenia wolności nadzwyczajnie obostrzonej (art. $38 \S 2$ k.k.), karze łącznej ograniczenia wolności (art. $86 \S 1$ k.k.) oraz w ramach sekwencji kar łącznych (art. 872 k.k.) ${ }^{27}$. W uzasadnieniu projektu ustawy nowelizacyjnej argumentowano, że wobec ogólnego wydłużenia czasu kary ograniczenia wolności ze względu na charakter konstytuujących ją obowiązków dłuższa perspektywa wykonywania kary ograniczenia wolności jest niefunkcjonalna przy zmieniających się

25 Ibidem, s. 9.

26 J. Majewski, op. cit., s. 54.

27 T. Sroka wymienia natomiast wyjątkowy wypadek, gdy kara ograniczenia wolności może być orzeczona w wymiarze przekraczającym 2 lata - T. Sroka, [w:] Nowelizacja prawa karnego 2015. Komentarz, red. W. Wróbel, Warszawa 2015, s. 94. 
warunkach na rynku pracy oraz zapotrzebowaniu na prace społecznie użyteczne ${ }^{28}$. Takie zrównanie górnej granicy kary ograniczenia wolności — w podstawowym jej wymiarze — z karą ograniczenia wolności nadzwyczajnie obostrzoną nie zostało w doktrynie jednoznacznie pozytywnie przyjęte. Podkreślano, że nie ma żadnych kryminalno-politycznych racji, które uzasadniałyby zrównanie górnej granicy kary ograniczenia wolności w jej podstawowym i obostrzonym wymiarze. Zwracano między innymi uwagę, że w nowym modelu kara ograniczenia wolności nie jest obligatoryjnie związana z obowiązkiem wykonania pracy, która może być tylko jedną z form kary ograniczenia wolności ${ }^{29}$. Wprawdzie wymiar kary ograniczenia wolności zrównano, w jej podstawowej postaci, z wymiarem kary nadzwyczajnie obostrzonej, jednakże istnieją rozmaite możliwości kształtowania dolegliwości tej kary poprzez konfigurację różnych obowiązków stanowiących jej treść. Poprzednio obowiązujący, maksymalny wymiar kary ograniczenia wolności, określony na 12 miesięcy, budził w doktrynie uzasadnione zastrzeżenia jako zbyt niski. Robert Zawłocki powątpiewał, czy zachodziły racjonalne powody kryminologiczne i polityczno-kryminalne takiego rozwiązania. Zdaniem tego autora podobne wątpliwości może budzić też minimalna, utrzymana przepisami nowelizacyjnymi, granica kary ograniczenia wolności, wynosząca jeden miesiąc, która stwarza wrażenie pozorności dolegliwości karnej $^{30}$. Wprowadzony ustawą nowelizacyjną maksymalny wymiar 2 lat kary ograniczenia wolności, przewidziany zresztą w kodeksie karnym z 1969 roku, wydaje się odpowiednim, postulowanym wcześniej, pułapem prawidłowego funkcjonowania kary ograniczenia wolności, przyjętym zresztą pozytywnie przez doktrynę prawa karnego.

Przepisy ustawy nowelizacyjnej z 2015 roku poważnie zreformowały treść kary ograniczenia wolności - obecnie wyznaczają ją różne, odmiennie skonfigurowane, dolegliwości. Niektóre mają charakter stały i obligatoryjny (art. $34 \S 2$ k.k.), inne są kształtowane przez sędziego

28 Uzasadnienie rządowego projektu..., s. 11.

29 Bliższa argumentacja por. T. Sroka, Koncepcja jedności kary ograniczenia wolności w nowym modelu tej kary po nowelizacji z 20 lutego 2015 r., Pal. 2015, nr 7-8, S. $50-51$.

30 R. Zawłocki, [w:] Kodeks karny. Część ogólna, t. 2, red. M. Królikowski, R. Zawłocki, Warszawa 2010, s. 54. 
(art. $34 \S 1 \mathrm{a})$. W obecnym uregulowaniu pozostawiono dwa stałe elementy znane z regulacji przed nowelizacją, w postaci: a) zakazu zmiany miejsca stałego pobytu oraz b) obowiązku udzielania wyjaśnień dotyczących przebiegu odbywania kary ${ }^{31}$. Ponieważ są to elementy stałe o charakterze obligatoryjnym, immamentnie związane z karą ograniczenia wolności, nie trzeba ich wymieniać w sentencji wyroku skazującego, chociaż niekiedy byłoby to celowe dla zapewnienia pełnej wiedzy skazanego o obciążających go obowiązkach i ograniczeniach ${ }^{32}$. Najistotniejsza zmiana w przepisach regulujących treść kary ograniczenia wolności dotyczyła natomiast elementów kształtowanych przez sędziego, określanych w doktrynie prawa karnego, jako elementy niestałe, mobilne kary ograniczenia wolności ${ }^{33}$. Dotychczasowe przepisy nie przewidywały bowiem kombinacji obowiązków wymienionych w art. 34 § 1a k.k. Obecnie, jak stanowi art. $34 \S 1$ b, sąd może orzec łącznie lub osobno: a) obowiązek wykonywania nieodpłatnej, kontrolowanej pracy na cele społeczne w wymiarze od 20 do 40 godzin w stosunku miesięcznym, b) potrącenia od $10 \%$ do $25 \%$ wynagrodzenia za pracę w stosunku miesięcznym na cele społeczne ${ }^{34}$. Jest to bez wątpienia zmiana rewolucyjna, nadająca karze ograniczenia wolności bardziej elastyczny charakter. Wspomniane obowiązki mogą być bowiem swobodnie dobierane przez sąd, z tym że przynajmniej jeden z tych obowiązków musi być orzeczony w wyroku skazującym. Nie ulega jednak wątpliwości, że przy doborze tych obowiązków oraz określaniu stopnia ich intensywności, a zatem przy tworzeniu różnych postaci kary ograniczenia wolności, sąd musi

31 Zgodnie z art. 60 k.k.w. sąd a także sądowy kurator zawodowy może w każdym czasie żądać od skazanego wyjaśnień dotyczących przebiegu odbywania kary ograniczenia wolności.

32 Por. także V. Konarska-Wrzosek, [w:] Kodeks karny. Komentarz, red. V. Konarska-Wrzosek, Warszawa 2016, s. 215; Z. Giętkowski, [w:] Kodeks karny. Komentarz, red. R.A. Stefański, Warszawa 2015, s. 295.

33 A. Grześkowiak, [w:] Kodeks karny. Komentarz, red. A. Grześkowiak, K. Wiak, Warszawa 2015, s. 297; T. Sroka, [w:] Nowelizacja prawa karnego..., s. 86. Obszernie o postaciach kary ograniczenia wolności por. też M. Szewczyk, [w:] System prawa karnego, t. 6. Kary i środki reakcji prawnokarnej, red. M. Melezini, Warszawa 2016, s. 217 n.

34 Art. $35 \S 2$ k.k. stanowi: „Potrącenie wynagrodzenia za pracę może być orzeczone wobec osoby zatrudnionej; w okresie, na jaki zostało orzeczone potrącenie, skazany nie może rozwiązać bez zgody sądu stosunku pracy". 
uwzględnić wskazania dyrektyw sądowego wymiaru kary (art. 53 k.k., a także art. $58 \S 2 \mathrm{a}$ k.k.). Ustawodawca nie wyznacza tu żadnych priorytetów, jeżeli chodzi o wybór między tymi postaciami kary ograniczenia wolności ${ }^{35}$. Komponując karę ograniczenia wolności, uwzględniającą kilka elementów określonych w art. $34 \S$ 1a k.k., sąd orzeka w istocie jedną karę, a nie tyle rodzajów kar, ile sposobów jej wykonania zostało wskazanych przez sąd. Kara ograniczenia wolności stanowi bowiem zawsze, mimo uwzględnienia różnych jej elementów, jedną niepodzielną karę $^{36}$. Warto jednak tu podkreślić, że obecnie kara ograniczenia wolności w postaci potrącenia $\mathrm{z}$ wynagrodzenia skazanego na cele społeczne ma równorzędny charakter z postacią kary ograniczenia wolności połączonej z wykonywaniem nieodpłatnej, kontrolowanej pracy na cele społeczne. Poprzednio forma kary ograniczenia wolności z potrąceniem z wynagrodzenia skazanego miała bowiem swoisty, uzupełniający charakter, orzekano ją bowiem w tej postaci zgodnie z dawną treścią art. 35 $\S 2$ k.k. „zamiast” obowiązku wykonywania pracy na cele społeczne. Zwracając uwagę na najistotniejsze cechy obecnej regulacji kary ograniczenia wolności, należy podkreślić utrzymanie przepisu o zakazie orzekania kary ograniczenia wolności w postaci obowiązku nieodpłatnej, kontrolowanej pracy, jeżeli stan zdrowia oskarżonego lub jego właściwości i warunki osobiste uzasadniają przekonanie, że oskarżony nie wykona tego obowiązku (art. 58 § 2a). Przepis ten uległ tylko niewielkiej zmianie redakcyjnej, uwzględniającej nową treść art. 34 § 1a k.k. Wspomniany zakaz jest nadal zasadny, chociaż ma mniejsze znaczenie, jako że sąd ma zawsze do wyboru dwa równorzędne obowiązki i zawsze może orzec samodzielnie wyłącznie obowiązek potrącenia z wynagrodzenia skazanego, o którym mowa w art. $34 \S 1$ la pkt 4.

Oprócz istotnej zmiany w wyznaczeniu górnej granicy kary ograniczenia wolności oraz uelastycznienia doboru elementów mobilnych kary ograniczenia wolności inną ważną cechą nowej postaci kary ograniczenia wolności jest nowo określony obszerny katalog obowiązków, które mogą być orzeczone przy karze ograniczenia wolności. Zgodnie z art. 34 $\S 3$ k.k. sąd, wymierzając karę ograniczenia wolności, może orzec obo-

35 J. Majewski, op. cit., s. 60-61; por. też T. Bojarski, [w:] Kodeks karny. Komentarz, red. T. Bojarski, Warszawa 2016, s. 155-156.

36 Obszernie o tym T. Sroka, Koncepcja jedności kary..., s. 48-50. 
wiązki wymienione w art. $72 \S 1$ pkt $2-7 \mathrm{a}$. W uzasadnieniu podkreślono, że kara ograniczenia wolności może obejmować elementy probacyjne, praktycznie tożsame z tymi, którymi sąd dysponuje przy orzekaniu kary pozbawienia wolności z warunkowym zawieszeniem jej wykonania ${ }^{37}$. Ponownie zatem może powstać wątpliwość, czy kara ograniczenia wolności jest samodzielną karą, czy staje się specyficznym środkiem probacyjnym. Stanowisko doktryny prawa karnego jest w tej kwestii, również po nowelizacji z 2015 roku, na ogół zgodne. Słusznie zwraca się uwagę, że dolegliwość wynikająca z zastosowania tych obowiązków nie należy do istoty kary ograniczenia wolności i nie wyznacza jej treści. Kara ograniczenia wolności wzmocniona obowiązkami probacyjnymi nie traci mimo ich orzeczenia charakteru kary bezwzględnej i nie jest środkiem probacyjnym ${ }^{38}$. Argumenty, jakie przemawiają za takim stanowiskiem, były już poprzednio wielokrotnie $\mathrm{w}$ doktrynie przytaczane ${ }^{39}$. Podnoszono w nich przede wszystkim, że kara ograniczenia wolności nie łączy się $\mathrm{z}$ wyznaczeniem okresu próby, w którym zobowiązuje się skazanego do wypełniania nałożonych obowiązków oraz do przestrzegania porządku prawnego. Odmienne są też negatywne konsekwencje za niewykonanie nałożonych obowiązków w razie orzeczenia kary ograniczenia wolności. Sąd może wprawdzie orzec zastępczą karę pozbawienia wolności (art. 65 k.k.w.), nie wyznacza się jej jednak w sentencji wyroku, tak jak przy warunkowym zawieszeniu wykonania kary pozbawienia wolności. Należy wyraźnie podkreślić, że orzekając karę ograniczenia wolności, sąd może orzec albo tylko jeden, albo wiele obowiązków, o których mowa w art. $72 \S 1$ pkt 2-7a, zważając jednak na stopień ich dolegliwości. Obowiązki te mogą być wykonywane równolegle przez cały czas odbywania kary ograniczenia wolności, ale też, jak podkreśla się w doktrynie, niektóre $\mathrm{z}$ nich mogą być wyznaczone w wyroku w sposób sekwencyjny ${ }^{40}$. Wprawdzie dobór i liczba nakładanych obowiązków przy orzeczeniu kary ograniczenia wolności należy do swobodnego uznania sędziowskiego, jednakże sędzia musi uwzględniać tu wskazania ogól-

37 Uzasadnienie rządowego projektu..., s. 10.

38 Por. między innymi J. Majewski, op. cit., s. 67; M. Szewczyk, [w:] System prawa karnego..., s. 205; T. Sroka, [w:] Nowelizacja prawa karnego..., s. 93-94.

39 Por. obszernie R. Giętkowski, Kara ograniczenia wolności..., s. 48-52.

40 T. Sroka, [w:] Nowelizacja prawa karnego..., s. 129-131. 
nych dyrektyw sądowego wymiaru kary, a zatem kierować się celami zarówno sprawiedliwościowymi, jak i prewencyjnymi. Należy tu wspomnieć, że zgodnie z art. 35 § 4 k.k.k. istnieje możliwość modyfikacji tych obowiązków w postępowaniu wykonawczym. Wymieniony przepis wskazuje na „odpowiednie” stosowanie w tym względzie art. 74 k.k.k., w którym jest mowa między innymi o możliwości ustanawiania, rozszerzania czy zmieniania orzeczonych obowiązków. Doktryna prawa karnego ma pewne zastrzeżenia do redakcji tego przepisu oraz wątpliwości, czy modyfikacje dokonywane w postępowaniu wykonawczym nie zmienią zasadniczo stopnia dolegliwości kary ograniczenia wolności określonej w wyroku skazującym ${ }^{41}$. Niezależnie od liczby i konfiguracji orzeczonych obowiązków należy przyjąć, że zmiany w tym zakresie w postępowaniu wykonawczym nie mogą przekroczyć stopnia dolegliwości obowiązków orzeczonych w wyroku skazującym. Oprócz obowiązków probacyjnych sąd, orzekając karę ograniczenia wolności, może orzec (fakultatywnie) świadczenie pieniężne wymienione w art. 39 pkt 7 k.k. Obecna regulacja podstawy prawnej do orzeczenia świadczenia pieniężnego obok kary ograniczenia wolności ma charakter uniwersalny ${ }^{42}$. Środek ten został bowiem wyraźnie przewidziany w przepisach regulujących dolegliwość kary ograniczenia wolności (art. 34 § 3 k.k.), a nie jak poprzednio w przepisach regulujących warunkowe zawieszenie wykonania kary pozbawienia wolności (art. $72 \S 2$ k.k.). Świadczenie pieniężne może stanowić ważną orzekaną fakultatywnie dolegliwość o charakterze materialnym. Zgodnie z ogólnym przepisem art. 43a k.k. granica świadczenia pieniężnego nie może przekroczyć 60 tys. zł. W ten sposób kara ograniczenia wolności została wzbogacona o elementy dolegliwości materialnej, które mogą w niektórych wypadkach znakomicie uzupełniać inne elementy kary ograniczenia wolności i umożliwiać realizację celów penalnych. Kolejną istotną zmianą charakteryzującą nowe ujęcie kary ograniczenia wolności było zniesienie możliwości warunkowego zawieszenia wykonania tej kary, przewidzianej przed nowelizacją z 2015 roku (art. 60 k.k.). Jak podkreślono w uzasadnieniu projektu nowelizacji, kara ograniczenia wolności jest w obecnym stanie nasycona wieloma elemen-

41 Por. bliżej J. Majewski, op. cit., s. 81-82; T. Sroka, [w:] Nowelizacja prawa karnego..., s. 129-131.

42 J. Majewski, op. cit., s. 67-68. 
tami probacyjnymi, które zostały tak wzmocnione, że orzekanie kary ograniczenia wolności w tej postaci nie znajduje uzasadnienia ${ }^{43}$.

Reasumując, trzeba podkreślić, że przepisy regulujące karę ograniczenia wolności pozwalają obecnie, w porównaniu z poprzednią regulacją, na elastyczniejsze kształtowanie dolegliwości kary ograniczenia wolności, umożliwiają tworzenie wielu jej postaci w zależności od konfiguracji elementów niestałych kary ograniczenia wolności, orzekanych albo łącznie, albo osobno. Sąd może też kształtować dolegliwość poszczególnych postaci tej kary, wyznaczając odpowiedni, in concreto, wymiar nieodpłatnej, kontrolowanej pracy bądź ustalać odpowiednią wysokość potrąceń z wynagrodzenia skazanego. Karę ograniczenia wolności mogą wzbogacać też dodatkowe obowiązki, które mogą być orzekane pojedynczo lub w zblokowaniu. Nie bez znaczenia jest podniesienie górnej granicy wymiaru kary ograniczenia wolności do 2 lat, stwarzające lepsze możliwości uwzględniania okoliczności danego przypadku i umożliwiające dłuższe i efektywniejsze jej oddziaływanie. Wybór poszczególnych wariantów kary ograniczenia wolności oraz kształtowanie jej dolegliwości poprzez dodatkowe obowiązki pozostawiony został wprawdzie swobodnemu uznaniu sędziowskiemu, jednakże nie ulega wątpliwości, że przy skonfigurowaniu tej kary konieczne będzie kierowanie się względami sprawiedliwościowymi oraz wskazaniami dyrektywy prewencji indywidualnej, jak też kształtowaniem świadomości prawnej społeczeństwa.

Przepisy ustawy nowelizacyjnej z 2015 roku wyznaczyły nowe kierunki polityki karnej, wśród których najistotniejsze było uczynienie z kar wolnościowych podstawowego środka zwalczania drobnej i średniej przestępczości. Realizacja priorytetów takiej polityki karnej wymagała przede wszystkim wprowadzenia przepisów ograniczających stosowanie kary pozbawienia wolności oraz odpowiednich zmian w regulacji kar wolnościowych, a zatem kary grzywny i kary ograniczenia wolności. Najpoważniejsze zmiany wyznaczające nową politykę karną objęły nie tylko przekształcenie kary ograniczenia wolności i nadanie jej bardziej elastycznego, wielowarstwowego charakteru, dostosowanego do wymagań poszczególnych przypadków, lecz również uzasadniały znaczne poszerzenia podstaw orzekania tej kary. Punktem wyjścia do radykalnych zmian w tym zakresie

43 Uzasadnienie rządowego projektu..., s. 15. 
stała się odmienna regulacja dyrektywy wyboru kary (art. $58 \S 1$ k.k.), ustalająca wyraźną zasadę preferencji kar wolnościowych w przypadkach przestępstw o niewysokim stopniu społecznej szkodliwości. Obecnie art. 58 § 1 k.k. stanowi: ,jeżeli ustawa przewiduje możliwość wyboru kary, a przestępstwo zagrożone jest karą pozbawienia wolności nieprzekraczającą 5 lat, sąd orzeka karę pozbawienia wolności tylko wtedy, gdy inna kara lub środek karny nie może spełnić celów kary". Nowe uregulowanie dyrektywy wyboru kary zatem wyraźnie wskazuje na znaczne ograniczenie orzekania kary pozbawienia wolności w każdej postaci, zarówno bezwzględnej, jak i z warunkowym zawieszeniem jej wykonania. W ten sposób powinno się osiągnąć, jak podkreślono w uzasadnieniu projektu nowelizacji, zamierzoną redukcję orzekania kary pozbawienia wolności z warunkowym zawieszeniem jej wykonania ${ }^{44}$. Czy jednak taka ustawowa regulacja spowoduje zmniejszenie orzekania kary pozbawienia wolności z warunkowym zawieszeniem oraz zwiększenie w praktyce roli kary grzywny i kary ograniczenia wolności? Niektórzy przedstawiciele doktryny prawa karnego wyrażają swoje wątpliwości, zauważając, że kierunki polityki karnej nie zawsze dają się zadekretować w ramach ogólnie ujętej reguły ${ }^{45}$. Zawarte jednak w art. $58 \S 1$ k.k. obligatoryjne wskazanie ustawowe do preferencji orzekania kar wolnościowych skłaniać będzie sędziego do rozważenia w każdym wypadku określonym w art. 58 § 1 k.k., czy wystarczające będzie orzeczenie grzywny lub kary ograniczenia wolności. $\mathrm{W}$ istocie bowiem przepis art. $58 \S 1 \mathrm{k} . \mathrm{k}$. nie powinien być traktowany jako samoistna norma, lecz jako kierunkowa ustawowa wskazówka niewyłączająca jednak całkowicie sędziowskiego uznania ${ }^{46}$. Mimo ograniczonego luzu decyzyjnego trudno nie dostrzec, że dyrektywa art. $58 \S 1$ k.k. wyraźnie umacnia rolę kary grzywny i kary ograniczenia wolności w zwalczaniu drobnej i średniej przestępczości.

Najistotniejszą jednak regulacją stwarzającą bardzo szerokie możliwości wymierzenia kar wolnościowych, również wobec poważnej przestępczości, jest nowy przepis art. 37a k.k., który, jeśli ująć rzecz najogólniej, umożliwia orzeczenie kar wolnościowych we wszystkich przypadkach przestępstw zagrożonych karą pozbawienia wolności nie-

44 Uzasadnienie rządowego projektu..., s. 13.

45 Tak T. Bojarski, op. cit., s. 216.

46 V. Konarska-Wrzosek, [w:] Kodeks karny. Komentarz, s. 359. 
przekraczającą 8 lat. Zgodnie z tym przepisem ,jeżeli ustawa przewiduje zagrożenie karą pozbawienia wolności nieprzekraczającą 8 lat, można zamiast tej kary orzec grzywnę albo karę ograniczenia wolności, o której mowa w art. $34 \S 1$ pkt 1 lub 4". Instytucja zamiany rodzaju kary na łagodniejszą była wprawdzie poprzednio ujęta w art. $58 \S 3$ k.k., jednakże obecna regulacja nie jest prostą kontynuacją uchylonego przepisu, różni się bowiem pod względem merytorycznym i redakcyjnym ${ }^{47}$. Istota obecnego uregulowania kary zamiennej budzi poważne wątpliwości i spory w doktrynie prawa karnego - szczególnie dyskusyjna jest ocena charakteru prawnego przepisu art. 37a k.k. Jest bowiem sporne, czy przepis ten przekształca ustawowe zagrożenia, zmieniając sankcje jednorodne w sankcje alternatywne, czy też stanowi dyrektywę sądowego wymiaru kary, skłaniającą do orzekania kar wolnościowych: kary grzywny lub kary ograniczenia wolności. Poglądy w tej kwestii są wyraźnie zróżnicowane. Nie wyjaśnia tej kwestii również uzasadnienie projektu ustawy, w którym wprawdzie zauważa się, że przepis ten przekształca sankcje jednorodne w alternatywne, lecz jednocześnie podkreśla się w nim, że przepis ten stanowi dyrektywę sądowego wymiaru kary do orzekania zamiast kary pozbawienia wolności, kar wolnościowych. Przy tym priorytet ten dotyczy jedynie przestępstw zagrożonych karą pozbawienia wolności do 5 lat ${ }^{48}$. Większość przedstawicieli doktryny prawa karnego odrzuca pogląd przypisujący normie zawartej w art. 37a k.k. charakter dyrektywy sądowego wymiaru kary, zauważając między innymi, że norma w art. 37a k.k. nie zawiera żadnych wskazówek co do tego, czym miałby się kierować sąd przy wyborze rodzaju i wysokości kary ${ }^{49}$. Można zatem przyjąć, że art. 37a k.k. dookreśla ustawowe zagrożenia za niektóre przestępstwa, a zatem przekształca w ten sposób sankcje proste w sankcje alternatywne, umożliwiając wprowadzenie kar wolnościowych: grzywny

${ }^{47}$ Art. 58 § 3 k.k. stanowił: ,Jeżeli przestępstwo jest zagrożone karą pozbawienia wolności nieprzekraczającą 5 lat, sąd może orzec zamiast kary pozbawienia wolności grzywnę albo karę ograniczenia wolności, w szczególności jeżeli orzeka równocześnie środek karny".

48 Uzasadnienie rządowego projektu..., s. 13.

49 Obszernie na ten temat J. Giezek, O sankcjach alternatywnych oraz możliwości wyboru i rodzaju wymierzonej kary, Pal. 2015, nr 7-8, s. 25 n. Por. też J. Majewski, op. cit., s. 85-86, 91; M. Małecki, [w:] Nowelizacja prawa karnego..., s. 286-288; odmienne zdanie M. Królikowski, R. Zawłocki, Prawo karne, Warszawa 2015, s. 327-328. 
i kary ograniczenia wolności do wszystkich dotychczasowych zagrożeń karą pozbawienia wolności nieprzekraczającą 8 lat. Akceptując zasadniczo słuszny kierunek zmian w regulacji prawnokarnych sposobów reakcji na przestępstwo, można jednak mieć obawy, czy nowe rozwiązanie nie jest zbyt radykalne, umożliwiając niemal w każdym przypadku wymierzenie kary grzywny lub ograniczenia wolności, nawet w wypadkach przestępstw o poważnym stopniu społecznej szkodliwości. Jedyną nadzieją, zdaniem Tadeusza Bojarskiego, jest racjonalne korzystanie przez sędziów z tak szeroko ujętych możliwości, szczególnie w odniesieniu do przestępstw poważnych ${ }^{50}$. Nie wnikając w skomplikowane teoretycznoprawne zagadnienia związane $\mathrm{z}$ ustawowym oraz sądowym wymiarem kary, podkreślić należy to, co dla niniejszego opracowania najważniejsze - że podstawy do orzeczenia kary ograniczenia wolności zostały, poprzez wprowadzenie przepisu art. 37a k.k., radykalnie rozszerzone, umożliwiając stosowanie tej kary nawet wobec bardzo poważnych występków.

$\mathrm{W}$ rozważaniach o zmianach $\mathrm{w}$ regulacji i podstawach stosowania kary ograniczenia wolności, po nowelizacji z 2015 roku, nie może zabraknąć kilku uwag o nowej instytucji tak zwanej kary mieszanej, uregulowanej w art. 37b k.k., której istota związana jest między innymi z wzmocnieniem roli kary ograniczenia wolności oraz możliwością jej szerokiego stosowania nawet $\mathrm{w}$ przypadkach poważnych przestępstw. Przepis art. 37b k.k., regulujący tak zwaną karę mieszaną, stwarza bowiem możliwość jednoczesnego orzeczenia dwóch kar: kary pozbawienia wolności i ograniczenia wolności za każdy występek zagrożony karą pozbawienia wolności, niezależnie od dolnej granicy ustawowego zagrożenia przewidzianego $\mathrm{w}$ ustawie. W takim wypadku wymiar kary pozbawienia wolności nie może przekraczać 3 miesięcy, a jeżeli górna granica ustawowego zagrożenia wynosi przynajmniej 10 lat -6 miesięcy. Karę ograniczenia wolności wymierza się $\mathrm{w}$ granicach do 2 lat, przy czym w pierwszej kolejności wykonuje się karę pozbawienia wolności, chyba że ustawa stanowi inaczej. Nowo wprowadzona instytucja tak zwanej kary mieszanej wzbudziła w nauce prawa karnego w pełni uzasadnione zainteresowanie. Niejasne było bowiem, czy przepis ten statuuje dyrektywę sądowego wymiaru kary, czy też współtworzy ustawowe zagroże-

50 T. Bojarski, op. cit., s. 165.

Nowa Kodyfikacja Prawa Karnego 48, 2018 (C) for this edition by CNS 
nie za występki zagrożone karą do 10 lat pozbawienia wolności. W motywach ustawodawczych nie rozstrzygnięto tej kwestii, podkreślając wprawdzie, że art. 37b k.k. zawiera ustawową dyrektywę wymiaru kary, przyjmując jednocześnie, że następuje modyfikacja systemu sankcji karnych pod typami czynów zabronionych ${ }^{51}$. Doktryna prawa karnego wyraźnie przychyliła się do poglądu, że przepis art. 37b k.k. wprowadza nową dyrektywę szczególną, która wskazuje sądowi na możliwość wymierzenia jednocześnie dwóch różnych rodzajów kary zgodnie z ogólnymi dyrektywami sądowego wymiaru kary ${ }^{52}$. Uzasadnione wątpliwości budzi jednakże, przyjęte w uzasadnieniu, określenie „kara mieszana”. Trudno się zgodzić, że w wypadku uregulowanym w art. $37 \mathrm{~b}$ k.k. dochodzi do „pomieszania” elementów dwóch rodzajów kar i do utworzenia jednego nowego rodzaju kary — „kary mieszanej”. Mimo iż doktryna prawa karnego posługuje się w większości wypadków określeniem kary mieszanej, należy przyjąć, że wspomniany przepis stwarza możliwość orzeczenia dwóch różnych rodzajów kar, a nie jednej nowej tak zwanej kary mieszanej, tym bardziej że kara taka nie została wprowadzona do katalogu kar w art. 32 k.k. Bardziej przekonujące jest moim zdaniem przyjęte przez niektórych przedstawicieli doktryny określenie ,sekwencja kar", oznaczające jednoczesne orzeczenie dwóch kar: pozbawienia wolności i ograniczenia wolności oraz sekwencyjne ich wykonanie ${ }^{53}$.

Oprócz sporów doktrynalnych dotyczących art. 37b k.k., które będą jeszcze wielokrotnie przedmiotem rozważań w publikacjach naukowych, istotniejsza dla rozważań o karze ograniczenia wolności wydaje się kwestia znaczenia, jakie dla polityki karnej będzie miała możliwość orzeczenia kary ograniczenia wolności jednocześnie z krótkoterminową karą pozbawienia wolności. Wytyczone nowelizacją z 2015 roku kierunki nowej polityki karnej akcentowały konieczność rozszerzenia stosowania kar

51 Uzasadnienie rządowego projektu..., s. 12.

52 A. Marek, V. Konarska-Wrzosek, op. cit., s. 367; V. Konarska-Wrzosek, [w:] Kodeks karny. Komentarz, s. 230; podobnie J. Majewski, op. cit., s. 95-96; M. Małecki, op. cit., s. 297.

53 Takie stanowisko uzasadnia obszernie M. Małecki, Sekwencja krótkoterminowej kary pozbawienia wolności i kary ograniczenia wolności (art. $37 b$ k.k.) — zagadnienia podstawowe, Pal. 2015, nr 7-8, s. 39 n.; idem, [w:] Nowelizacja prawa karnego..., s. 296-298. Por. też Z. Sienkiewicz, [w:] Prawo karne materialne. Część ogólna i szczególna, red. M. Bojarski, Warszawa 2017, s. 358.

Nowa Kodyfikacja Prawa Karnego 48, 2018 (C) for this edition by CNS 
wolnościowych oraz wyraźne ograniczenie stosowania kary pozbawienia wolności z warunkowym zawieszeniem jej wykonania. O ile możliwości szerokiego stosowania kary ograniczenia wolności wobec drobnej i średniej przestępczości wynikają z nowego przepisu art. 37a k.k., o tyle przepis art. 37b k.k. stwarza możliwości orzeczenia (nawet w wypadku poważnych występków) zamiast uprzednio szeroko stosowanej w praktyce krótkoterminowej kary pozbawienia wolności z warunkowym zawieszeniem jej wykonania — orzeczenia krótkoterminowej kary pozbawienia wolności i kary ograniczenia wolności (tzw. kary mieszanej). Orzeczenie takiej kary pozbawienia wolności ma w tym wypadku, w pewnym sensie, charakter symboliczny, decydująca natomiast będzie kara ograniczenia wolności, której dolegliwości mogą być, zgodnie z nową regulacją tej kary, elastycznie ukształtowane ${ }^{54}$. Jak wynika z motywów ustawodawczych, kara ograniczenia wolności, która pozbawiona jest silnego stygmatyzującego, skutku może być w tym wypadku skierowana na ugruntowanie społecznie pożądanych postaw skazanego ${ }^{55}$. Doktryna prawa karnego wyraźnie podkreśla, że jednoczesne orzeczenie krótkoterminowej kary pozbawienia wolności i kary ograniczenia wolności (tzw. kara mieszana) stanowi właściwe rozwiązanie, które może zastąpić, od lat krytykowaną, praktykę szerokiego stosowania krótkoterminowej kary pozbawienia wolności z warunkowym zawieszeniem jej wykonania ${ }^{56}$.

Dotychczasowe rozważania o karze ograniczenia wolności skłaniają do ogólniejszej refleksji nie tylko nad nowym kształtem tej kary, lecz także nad wyznaczeniem karze ograniczenia wolności głównej roli w nowej polityce karnej. Zgodnie z nowymi założeniami polityczno-kryminalnymi ustawy nowelizacyjnej z 2015 roku kara ograniczenia wolności powinna niemal w całości zastąpić dotychczasową praktykę szerokiego stosowania kary pozbawienia wolności z warunkowym zawieszeniem jej wykonania. Realizacja takich założeń wymagała nie tylko stworzenia szerokich podstaw do orzekania kar wolnościowych, lecz również rady-

54 Należy też podkreślić, że kara ograniczenia wolności orzeczona na podstawie art. $37 \mathrm{~b}$ k.k. może być orzeczona w każdej postaci przewidzianej w art. 34 § 1a k.k.

55 Uzasadnienie rządowego projektu..., s. 12.

56 Między innymi T. Bojarski, op. cit., s. 166; M. Królikowski, R. Zawłocki, op. cit., s. 346; V. Konarska-Wrzosek, [w:] Kodeks karny. Komentarz, s. 229; M. Małecki, Sekwencja krótkoterminowej..., s. 46. 
kalnej zmiany modelu kary ograniczenia wolności. Nie ulega wątpliwości, że nowa regulacja modelu kary ograniczenia wolności uczyniła z tej kary elastyczny, wielopostaciowy środek reakcji karnej na przestępstwo. Możliwość swobodnej konfiguracji rozmaitych dolegliwości zawartych w karze ograniczenia wolności, wyznaczenia różnych obowiązków probacyjnych oraz podniesienie górnych granic jej wymiaru powoduje, że kara ograniczenia wolności powinna być, zgodnie z polityczno-krymianalnymi kierunkami, alternatywą nie tylko dla kary grzywny oraz kary pozbawienia wolności z warunkowym zawieszeniem jej wykonania, lecz także nawet krótkoterminowej kary pozbawienia wolności. Mimo ogólnie pozytywnej oceny nowego modelu kary ograniczenia wolności trudno obecnie przewidzieć, czy wszystkie możliwości tkwiące w karze ograniczenia wolności będą w praktyce, konkretnych wypadkach, właściwie dobierane i wykorzystane, a zatem czy kara ta może stać się wiodąca w wypadkach nie tylko drobnej czy średniej, ale nawet poważnej przestępczości. O ostatecznej roli kary ograniczenia wolności w polityce karnej przesądzi zatem nie tyle nowa, atrakcyjnie ujęta regulacja kary ograniczenia wolności oraz szerokie podstawy jej stosowania, ile racjonalna praktyka sądowa wykorzystująca prawidłowo poszczególne postaci kary ograniczenia wolności do rozpatrywania konkretnych przypadków.

\section{On restriction of liberty in the light of the amended Criminal Code}

\section{Summary}

In the present article the author examines the question of restriction of liberty in the light of the amended Criminal Code of 2015. In the new Civil Code restriction of liberty has become a means of a flexible response to a crime, making it possible to shape the severity of this penalty in a variety of ways. The amended provisions of the Criminal Code have considerably expanded the scope of its application, making it possible to impose this penalty not only in the case of petty and medium-severity but also serious offences. Restriction of liberty has become a penalty competing with fines and, above all, with suspended custodial sentence, the application of which, under the new provisions, should be considerably limited.

Keywords: Criminal Code, restriction of liberty, amended provisions. 